\title{
The Bioefficacy of Selected Insecticides against Field Bean (Lablab purpureus) Pod Borer Complex
}

\author{
K.M. Rashmi ${ }^{1}$, K.N. Muniswamy Gowda ${ }^{2}$, B. Tambat ${ }^{2}$, \\ N. Umashankar Kumar ${ }^{2}$ and L. Vijayakumar ${ }^{1}$ \\ ${ }^{1}$ College of Agriculture, VC form Mandya, India \\ ${ }^{2}$ College of Agriculture, Karekere, Hassan-573 225, India \\ *Corresponding author
}

Keywords

Bioefficacy, Field bean, Insecticide, Cost benefic ratio, Chlorantraniliprole

Article Info

Accepted:

30 May 2020

Available Online:

10 June 2020
A B S T R A C T

Among nine insecticide molecules tested for their bio-efficacy against major pod borers the foliar sprays of chlorantraniliprole $18.5 \mathrm{SC} @ 0.15 \mathrm{ml} / \mathrm{l}$ was found to be most effective against all the pod borers. The efficacy of chlorantraniliprole $18.5 \mathrm{SC}$ was on par with spinosad @ $0.15 \mathrm{ml} / \mathrm{l}$ and emamectin benzoate @ $0.2 \mathrm{~g} / \mathrm{l}$. Similarly, the least per cent pod damage was observed in Chlorantraniliprole 18.5 SC treatment (12.57\%) followed by Emamectin benzoate 5 SG $(15.83 \%)$ and Spinosad 45 SC $(17.60 \%)$ which were statistically on par with each other. The results on the cost economics of pod borer complex management revealed that, among the treatments the pod yield was maximum (27.45 q/ha) in Chlorantraniliprole 18.5 SC followed by Spinosad 45 SC (25.48 q/ha) and Emamectin benzoate $5 \mathrm{SG}(24.80 \mathrm{q} / \mathrm{ha})$ which were statistically on par with each other. Accordingly, the highest net profit (Rs.63969/ha) was documented in chlorantraniliprole 18.5 SC. This was followed by spinosad 45 SC (Rs.58019/ha), emamectin benzoate 5 SG (Rs.56807/ha). The highest cost benefit ratio was obtained in chlorantraniliprole $18.5 \mathrm{SC}$ (1: 3.48). This was followed by emamectin benzoate 5 SG (1: 3.23), spinosad 45 SC (1: $3.15)$.

\section{Introduction}

Lablab purpureus (L.), commonly called as field bean is one of the ancient leguminous crops cultivated mainly in southern parts of India. Though the crop is cultivated in almost all regions of Karnataka, it is highly grown as a mixed crop with finger millet and sorghum and to a smaller extent as a pure crop under rainfed as well as irrigated conditions. The damage by insect pests is considered as one of the major drawbacks in achieving the potential yield in field bean. Several of pests severely ravage the buds, flowers and developing seeds of bean crop resulting in crop loss. Govindan (1974) reported around 55 species of insects and one species of mite feeding on crop from seedling stage to harvest in Karnataka. 
Among sucking pests lablab bug, Coptosoma cribraria (Fabricius), Riptortus pedestris (Fabricius) and Nezara viridula (Linnaeus) occurred commonly in large numbers throughout the cropping period (Govindan,1974). The significant crop damage was attributed to the pod borer complex including Helicoverpa armigera (Hubner), Adisura atkinsoni (Moore), Maruca testulalis (Geyer), Etiella zinckenella (Treitschke), Cydia ptychora (Meyrick), Exelastis atomosa (Walshinghan), Sphenarches caffer (Zeller) and Lampides boeticus (Linnaeus) and Callosobruchus theobromae (L.) which are of considerable importance causing 80 per cent pod damage (Katagihallimath and Siddappaji, 1962). The inflorescence is attacked by several species of borers, of which E. atomosa, A. atkinsoni and $H$. armigera have been considered as major pests. Currently, spotted borer, $M$. vitrata is attaining a major pest status on Lablab varieties, blooming throughout the year. The seed yield loss caused by A. atkinsoni has reported to be more than 95 per cent (Chakravarthy, 1983) and pod damage, more than 49.43 per cent (Mallikarjunappa, 1989).

By considering the seriousness of damage caused by the pod borers it is felt necessary to find efficient and precise control measures. Since, L. purpureus is a vegetable crop, the eco-friendly suppression methods like the use of resistant varieties and application of needbased pesticides based on information of insect-pest dynamics should be adopted.

Since, many of the old insecticides have lost their efficacy or become obsolete in recent days due to development of resistance in the insects or their residual toxicity problem are replaced by new generation molecules which are less toxic to mammals, birds, and fish and with high insecticidal potency. These new molecules are comparatively safer to natural enemies, honeybees and other pollinators than old generation molecules (Singh and Kumar, 2012). To overcome the ill-effects of old insecticides, several new molecules with new chemistry and novel mode of action were introduced so it becomes necessary to test their efficacy and to find out a more simple and economical control measure.

\section{Materials and Methods}

To study the bio efficacy of selected newer insecticides on pod borer complex, a field experiment was laid out under RCBD (Randomized complete block design) with 10 treatments and three replications including an untreated control (Table 1). A popular variety, HA-4 was raised in Kharif 2017 with a spacing of $45 \mathrm{X} 15 \mathrm{~cm}$ between rows and plants, respectively. For each replication a plot size of $4.5 \times 3 \mathrm{~m}$ was maintained. Nine selected insecticides were assessed in comparison with untreated check against field bean pod borer complex (Table 1). The insecticides were sprayed twice, first spray was given at $50 \%$ flowering (45 DAS) and second spray was given at 15 days after first spray (60 DAS) by using high volume knapsack sprayer with a spray volume of 400500 1/ha.

The observations on the number of pod borer larvae/10 designated plants in each plot were recorded. Pre-count observations were made on a day before spray and post count observations were made on $1,5,10$ and 15 days after insecticide treatment. The data obtained were subjected to suitable transformation. Further, the data on pod borers in each treatment were subjected to ANOVA (Gomez and Gomez, 1984; Hosmand, 1988).

The per cent reduction over untreated control was worked out using modified Abbot's formula given below. 


$$
\mathrm{P}=\frac{100 \times 1-\left(\mathrm{Ta} \times \mathrm{C}_{\mathrm{b}}\right)}{\left.--\mathrm{Tb}^{\mathrm{C}} \times \mathrm{Ca}\right)}
$$

Where, $\mathrm{P}=$ Percentage population reduction over control

$\mathrm{Ta}=$ Population in treatment after spray

$\mathrm{Ca}=$ Population in control after spray

$\mathrm{Tb}=$ Population in treatment before spray

$\mathrm{Cb}=$ Population in control before spray (Fleming and Ratnakaran, 1985)

\section{Pod damage}

At the time of harvest, data on total number of pods and number of damaged pods in ten designated plants in each plot were recorded and per cent pod damage was computed by using following formula.

Percentage pod damage $=$

Total number of damaged pods

Total number of pods 100

\section{Pod yield}

The pod yield was recorded on the net plot area basis which was later converted to $\mathrm{q} / \mathrm{ha}$ and finally subjected to statistical analysis.

The per cent increase in yield over control was calculated by using the formula:

Yield increase over control $(\%)=\frac{\mathrm{T}-\mathrm{C} \times 100}{-------}$

Where, $\mathrm{T}=$ Yield of respective treatment $(\mathrm{q} / \mathrm{ha}), \mathrm{C}=$ Yield of control $(\mathrm{q} / \mathrm{ha})$

Benefit to cost ratio was also calculated for all the treatments by using the formula:

Cost benefit ratio $=\frac{\text { Net profit (Rs.) }}{-- \text { Total cost }^{\text {Rs. }} \text { ) }}$

\author{
Results and Discussion \\ Population of plume moth, E. atomosa
}

\section{First spray}

The larval population of plume moth, $E$. atomosa in all the treatments was uniform a day before application of treatments as indicated by the non-significant differences among the various treatments (Table 2). However, after one day of spraying (DAS), among the selected insecticides, the lowest larval population was noticed in chlorantraniliprole 18.5 SC treatment $(0.47$ larvae/ plant) which stood on par with spinosad 45 SC (0.59 larvae/ plant) and emamectin benzoate 5 SG (0.71 larvae/ plant). Which were followed by indoxacarb 14.5 SC (1.08 larvae/ plant) and thiodicarb 75 WP (1.20 larvae/ plant). The highest larval population was noticed in biopower $50 \mathrm{WP}$ treatment (1.93 larvae/ plant). However, all the treatments were significantly superior over control.

Five days after spray, the lowest larval population was found in chlorantraniliprole 18.5 SC treatment (1.04 larvae/ plant) which was on par with emamectin benzoate 5 SG (1.15 larvae/ plant) and spinosad 45 SC (1.18 larvae/ plant). Which were followed by indoxacarb 14.5 SC (1.39 larvae/ plant) and thiodicarb 75 WP (1.48 larvae/ plant). The highest larval population was noticed in biopower 50 WP treatment (1.86 larvae/ plant). However, all the treatments were significantly superior over control.

Ten days after spray, all the treatments were significantly superior over control. However, the lowest larval population was noticed in chlorantraniliprole 18.5 SC treatment (1.27 larvae/ plant) which was on par with spinosad 45 SC (1.47 larvae/ plant) and emamectin benzoate $5 \mathrm{SG}$ (1.98 larvae/ plant). Which 
were followed by indoxacarb 14.5 SC (2.44 larvae/ plant) and thiodicarb 75 WP (2.64 larvae/ plant). The highest larval population was noticed in biopower $50 \mathrm{WP}$ treatment (3.34 larvae/ plant).

Fifteen days after spray, the lowest larval population was noticed in chlorantraniliprole 18.5 SC treatment (3.30 larvae/ plant) which was on par with spinosad 45 SC (3.38 larvae/ plant) and emamectin benzoate 5 SG (3.46 larvae/ plant). Which were followed by indoxacarb 14.5 SC (3.61 larvae/ plant) and thiodicarb 75 WP (4.14 larvae/ plant). The highest larval population was noticed in biopower 50 WP treatment (6.08 larvae/ plant). However, all the treatments were significantly superior over control.

\section{Second spray}

One day before second spray the larval population varied from 3.30 - 6.59 larvae/ plant and there was significant difference in the larval population among the treatments (Table 2).

One day after spraying, among the selected insecticides, the lowest larval population was noticed in chlorantraniliprole $18.5 \mathrm{SC}$ treatment (0.78 larvae/ plant) which stood on par with spinosad $45 \mathrm{SC}$ (0.89 larvae/ plant) and emamectin benzoate 5 SG (1 larvae/ plant). Which were followed by thiodicarb 75 WP (1.18 larvae/ plant) and indoxacarb 14.5 SC (1.22 larvae/ plant). The highest larval population was noticed in biopower $50 \mathrm{WP}$ treatment (5.79 larvae/ plant). However, all the treatments were significantly superior over control.

Five days after imposition of treatments, all the treatments were significantly superior over control. The lowest larval population was registered in chlorantraniliprole 18.5 SC with 0.88 larvae/ plant and was on par with the treatments spinosad $45 \mathrm{SC}$ (0.95 larvae/ plant) and emamectin benzoate 5 SG (1.10 larvae/ plant). Which were followed by indoxacarb 14.5 SC (1.36 larvae/ plant) and thiodicarb 75 WP (1.45 larvae/ plant). The highest larval population was noticed in biopower 50 WP treatment (4.68 larvae/ plant).

Ten days after spray, all the treatments were significantly superior over control. However, the lowest larval population was noticed in chlorantraniliprole 18.5 SC treatment (1.12 larvae/ plant) which was on par with spinosad 45 SC (1.14 larvae/ plant) and emamectin benzoate $5 \mathrm{SG}$ (1.24 larvae/ plant). Which were followed by indoxacarb 14.5 SC (1.43 larvae/ plant) and thiodicarb 75 WP (1.58 larvae/ plant). The highest larval population was noticed in biopower $50 \mathrm{WP}$ treatment (4.93 larvae/ plant).

Fifteen days after spray, the lowest larval population was recorded in chlorantraniliprole 18.5 SC treatment (1.67 larvae/ plant) which was on par with emamectin benzoate $5 \mathrm{SG}$ (1.88 larvae/ plant) and spinosad 45 SC (1.93 larvae/ plant). Which were followed by indoxacarb 14.5 SC (2.07 larvae/ plant) and thiodicarb $75 \mathrm{WP}$ (2.21 larvae/ plant). The highest larval population was noticed in biopower 50 WP treatment (5.32 larvae/ plant). However, all the treatments were significantly superior over control.

After imposition of first and second spray the mean percent reduction of E. atomosa population was higher in chlorantraniliprole 18.5 SC treatment $(79.36 \%)$ followed by emamectin benzoate $5 \mathrm{SG}(76.76 \%)$ and spinosad 45 SC (76.14\%). However, the lowest per cent reduction over control was observed in biopower $50 \mathrm{WP}$ treatment $(34.24 \%)$.

After second spray, the insecticides in the decreasing order of their efficacy were chlorantraniliprole $18.5 \mathrm{SC}>$ emamectin 
benzoate $5 \mathrm{SG}>$ spinosad $45 \mathrm{SC}>$ indoxacarb 14.5 $\mathrm{SC}>$ thiodicarb $75 \mathrm{WP}>$ lambda cyhalothrin $5 \mathrm{EC}>$ azadirachtin $10000 \mathrm{ppm}>$ fenvelerate $0.4 \% \mathrm{D}$.

Similarly, Jat et al., (2017) manifested the superiority of spinosad $45 \mathrm{SC}$ and indoxacarb 14.5 SC against pod borer complex in field bean crop. Kolarath et al., (2014) also reported the efficacy of emamectin benzoate 5 SG was higher against pod borers compared to other treatments. However, no studies were recorded for the use of chlorantraniliprole against plume moth. But can be compared to experimental results by Sreekanth et al., (2013) who indicated that the number of larvae per plant were lowest in plots treated with chlorantraniliprole $20 \mathrm{SC}$, flubendiamide $480 \mathrm{SC}$ and spinosad $45 \mathrm{SC}$ against $\mathrm{H}$. armgiera.

\section{Population of $\boldsymbol{H}$. armigera}

The non-significant differences among the various treatments were observed prior to application of insecticides which indicated the uniform distribution of the $H$. armigera population in the experimental plots (Table $3)$. The larval population ranged from $2.17-$ 3.03 larvae/ plant.

However, one day after spraying, among the treatments, the least larval number was recorded in treatment chlorantraniliprole 18.5 SC (0.53 larvae/ plant) which was on par with spinosad 45 SC (0.65 larvae/ plant) and emamectin benzoate 5 SG (0.78 larvae/ plant). Which were followed by thiodicarb 75 WP (1.14 larvae/ plant) and indoxacarb 14.5 SC (1.28 larvae/ plant). The highest larval population was noticed in biopower $50 \mathrm{WP}$ treatment (2.00 larvae/ plant). However, all the treatments were significantly superior over control.

After 5 days of first spray, among the treatments, chlorantraniliprole 18.5 SC was found significantly superior over rest of the insecticides which recorded lowest larval population of 0.94 larvae/ plant which stood on par with spinosad 45 SC (1.07 larvae/ plant) and emamectin benzoate $5 \mathrm{SG}$ (1.12 larvae/ plant). Which were followed by thiodicarb 75 WP (1.36 larvae/ plant) and indoxacarb 14.5 SC (1.41 larvae/ plant). The highest larval population was noticed in biopower 50 WP treatment (2.27 larvae/ plant). However, the untreated control plots recorded as high as 3.55 larvae per plant.

At 10 and 15 days after spraying also, a similar trend on the efficacy of insecticides was observed. The larval population ranged from 1.17 to 4.21 larvae/ plant and 2.25 to 4.43 larvae/ plant at 10 days and 15 days after first spray, respectively. chlorantraniliprole 18.5 SC was found superior over rest of the insecticides which recorded lowest larval population of 1.17 larvae/ plant and 2.25 larvae/ plant at 10 and 15 days after spray, which stood on par with spinosad 45 SC (1.34 and 2.31 larvae/ plant at 10 and 15 days after spray, respectively) and emamectin benzoate 5 SG (1.56 and 2.37 larvae/ plant at 10 and 15 days after spray, respectively). Which were followed by thiodicarb $75 \mathrm{WP}$ (2.41 and 2.39 larvae/ plant at 10 and 15 days after spray, respectively) and indoxacarb 14.5 SC (2.31 and 2.55 larvae/ plant at 10 and 15 days after spray, respectively).

The highest larval population was noticed in biopower 50 WP treatment (3.04 and 3.17 larvae/ plant at 10 and 15 days after spray, respectively). However, all the treatments were superior over control in their efficacy.

\section{Second spray}

One day before treatment the larval population ranged from $2.25-4.43$ larvae/ plant and there was significant difference in the larval population among the treatments (Table 3). One day after treatments used, 
among the selected insecticides, the lowest larval population was registered in chlorantraniliprole $18.5 \mathrm{SC}$ treatment $(0.51$ larvae/ plant) which stood on par with spinosad 45 SC (0.74 larvae/ plant) and emamectin benzoate 5 SG (0.79 larvae/ plant). Which were followed by thiodicarb 75 WP (0.92 larvae/ plant) and indoxacarb 14.5 SC (1.17 larvae/ plant). The highest larval population was noticed in biopower $50 \mathrm{WP}$ treatment (2.91 larvae/ plant). However, all the treatments were significantly superior over control.

Five days after spray, the lowest larval population was recorded in emamectin benzoate $5 \mathrm{SG}$ (0.92 larvae/ plant) which was on par with chlorantraniliprole 18.5 SC treatment (0.93 larvae/ plant) and spinosad 45 SC (1.09 larvae/ plant). Which were followed by indoxacarb 14.5 SC (1.67 larvae/ plant), thiodicarb $75 \mathrm{WP}$ (1.81 larvae/ plant) and azadirachtin 10000 ppm (1.91 larvae/ plant). Whereas, the highest larval population was noticed in biopower 50 WP treatment (3.04 larvae/ plant). However, all the treatments were significantly superior over control.

Ten days after treatments used, all the treatments were significantly superior over control. The larval population ranged from 1.42 to 5.32 larvae/ plant. The lowest larval population was documented in chlorantraniliprole 18.5 SC with 1.42 larvae/ plant and was on par with the treatments emamectin benzoate $5 \mathrm{SG}$ (1.65 larvae/ plant) and spinosad $45 \mathrm{SC}$ (1.76 larvae/ plant). Which were followed by indoxacarb 14.5 SC (2.21 larvae/ plant) and thiodicarb $75 \mathrm{WP}$ (2.40 larvae/ plant). The highest larval population was noticed in biopower $50 \mathrm{WP}$ treatment (3.59 larvae/ plant). Fifteen days after spray, all the treatments were significantly superior over control. However, the lowest larval population was noticed in chlorantraniliprole 18.5 SC treatment (1.72 larvae/ plant) which was on par with spinosad
45 SC (1.73 larvae/ plant) and emamectin benzoate $5 \mathrm{SG}$ (1.83 larvae/ plant). Which were followed by indoxacarb 14.5 SC (2.81 larvae/ plant) and thiodicarb 75 WP (2.84 larvae/ plant). The highest larval population was noticed in biopower $50 \mathrm{WP}$ treatment (4.21 larvae/ plant).

The mean per cent reduction of $\mathrm{H}$. armigera after imposing first and second spray was higher in chlorantraniliprole 18.5 SC treatment $(71.52 \%)$ followed by spinosad 45 SC $(71.35 \%)$ and emamectin benzoate 5 SG $(69.70 \%)$. However, the lowest per cent reduction over control was observed in biopower 50 WP treatment (30.30\%).

After second spray, the treatments which recorded less larval population are arranged in the increasing order were chlorantraniliprole 18.5 SC < emamectin benzoate $5 \mathrm{SG}<$ spinosad 45 SC < indoxacarb 14.5 SC < thiodicarb $75 \mathrm{WP}<$ azadirachtin $10000 \mathrm{ppm}<$ fenvelerate $0.4 \% \mathrm{D}<$ lambda cyhalothrin 5 EC $<$ biopower 50 WP.

The present findings are in accordance with Neharkar et al., (2017) who advocated the treatment with flubendiamide 20 WDG resulted in lowest population of $H$. armigera. and was found to be on par with chlorantraniliprole 18.5 SC followed by spinosad $45 \mathrm{SC}$, emamectin benzoate $5 \mathrm{SG}$ and indoxacarb 14.5 SC in pigeon pea. The experimental results by Sreekanth et al., (2013) also proved that the number of larvae per plant were lowest in plots that received chlorantraniliprole $20 \mathrm{SC}$, flubendiamide 480 SC and spinosad 45 SC treatments.

\section{Population of $A$. atkinsoni}

\section{First spray}

The larval population of $A$. atkinsoni in all the treatments was practically uniform a day before application of treatments as indicated 
by the non-significant differences among the various treatments (Table 4). The larval population ranged from 1.57 to 2.43 larvae/ plant.

However, one day after spraying (DAS), the lowest larval population was noticed in chlorantraniliprole $18.5 \mathrm{SC}$ treatment $(0.63$ larvae/ plant) which stood on par with spinosad 45 SC (0.75 larvae/ plant) and emamectin benzoate 5 SG (0.84 larvae/ plant). Which were followed by indoxacarb 14.5 SC (1.24 larvae/ plant) and thiodicarb 75 WP (1.38 larvae/ plant). The highest larval population was noticed in biopower $50 \mathrm{WP}$ treatment (2.10 larvae/ plant). However, all the treatments were significantly superior over control.

Five days after spray, the lowest larval population was noticed in chlorantraniliprole 18.5 SC treatment (0.88 larvae/ plant) followed by and emamectin benzoate $5 \mathrm{SG}$ (0.92 larvae/ plant) and spinosad 45 SC (1.01 larvae/ plant) which were on par with chlorantraniliprole. Which were followed by thiodicarb $75 \mathrm{WP}$ (1.41 larvae/ plant) and indoxacarb 14.5 SC (1.53 larvae/ plant). The highest larval population was noticed in biopower $50 \mathrm{WP}$ treatment (2.26 larvae/ plant). However, all the treatments were significantly superior over control.

Ten days after spray, all the treatments were significantly superior over control. The lowest larval population was noticed in emamectin benzoate $5 \mathrm{SG}$ (1.76 larvae/ plant) which was on par with chlorantraniliprole 18.5 SC treatment (1.95 larvae/ plant) spinosad $45 \mathrm{SC}$ (2.06 larvae/ plant) and. Which were followed by indoxacarb $14.5 \mathrm{SC}$ (2.11 larvae/ plant) and thiodicarb $75 \mathrm{WP}$ (2.12 larvae/ plant). The highest larval population was noticed in biopower 50 WP treatment (2.68 larvae/ plant).

Fifteen days after spray, the lowest larval population was noticed in chlorantraniliprole 18.5 SC treatment (2.00 larvae/ plant) which was on par with emamectin benzoate $5 \mathrm{SG}$ (2.08 larvae/ plant) and spinosad $45 \mathrm{SC}(2.16$ larvae/ plant), followed by thiodicarb $75 \mathrm{WP}$ (2.31 larvae/ plant) and indoxacarb 14.5 SC (2.64 larvae/ plant). The highest larval population was noticed in biopower $50 \mathrm{WP}$ treatment (3.41 larvae/ plant). However, all the treatments were significantly superior over control.

\section{Second spray}

One day before imposition of treatment, the larval population varied from 2.00 to 3.66 larvae/ plant. However there was significant difference in the larval population among the treatments (Table 4).

One day after spraying, the lowest larval population was documented in chlorantraniliprole 18.5 SC treatment (0.63 larvae/ plant) which stood at par with spinosad 45 SC (0.87 larvae/ plant) and emamectin benzoate $5 \mathrm{SG}$ (0.88 larvae/ plant). Which were followed by indoxacarb 14.5 SC (1.15 larvae/ plant) and thiodicarb 75 WP (1.24 larvae/ plant). The highest larval population was noticed in biopower $50 \mathrm{WP}$ treatment (3.07 larvae/ plant). However, all the treatments were significantly superior over control.

Five days after treatments were used, all the treatments were significantly superior over control. The lowest larval population was registered in chlorantraniliprole $18.5 \mathrm{SC}$ which recorded 0.87 larvae/ plant and was on par with the treatments spinosad 45 SC (0.92 larvae/ plant) and emamectin benzoate $5 \mathrm{SG}$ (1.03 larvae/ plant). Which were followed by indoxacarb 14.5 SC (1.19 larvae/ plant) and thiodicarb 75 WP (1.46 larvae/ plant). The highest larval population was noticed in biopower 50 WP treatment (2.43 larvae/ 
plant). Ten days after spraying, all the treatments were significantly superior over control. However, the lowest larval population was noticed in spinosad $45 \mathrm{SC}$ (1.65 larvae/ plant) which was on par with chlorantraniliprole 18.5 SC treatment (1.90 larvae/ plant) and emamectin benzoate $5 \mathrm{SG}$ (2.06 larvae/ plant). Which were followed by thiodicarb 75 WP (2.18 larvae/ plant) and indoxacarb 14.5 SC (2.31 larvae/ plant). The highest larval population was noticed in biopower 50 WP treatment (2.66 larvae/ plant).

Fifteen days after spraying, the lowest larval population was observed in chlorantraniliprole 18.5 SC treatment (1.65 larvae/ plant) which was on par with spinosad 45 SC (1.90 larvae/ plant) and emamectin benzoate $5 \mathrm{SG}$ (2.06 larvae/ plant). Which were followed by indoxacarb 14.5 SC (2.51 larvae/ plant) and thiodicarb 75 WP (2.84 larvae/ plant). The highest larval population was noticed in biopower $50 \mathrm{WP}$ treatment (3.86 larvae/ plant). However, all the treatments were significantly superior over control.

After imposition of first and second spray the mean percent reduction of $\mathrm{E}$. atomosa population was higher in chlorantraniliprole 18.5 SC treatment $(66.05 \%)$ followed by spinosad 45 SC (60.91\%) and emamectin benzoate 5 SG (57.61\%). However, the lowest per cent reduction over control was observed in biopower $50 \mathrm{WP}$ treatment $(20.58 \%)$.

At the end of second spray, the insecticides in the decreasing order of their efficacy against A. atkinsoni were chlorantraniliprole 18.5 SC $>$ spinosad $45 \mathrm{SC}>$ emamectin benzoate $5 \mathrm{SG}$ $>$ indoxacarb 14.5 $\mathrm{SC}>$ thiodicarb $75 \mathrm{WP}>$ lambda cyhalothrin $5 \mathrm{EC}>$ azadirachtin $10000 \mathrm{ppm}>$ fenvelerate $0.4 \% \mathrm{D}>$ biopower 50 WP. Mallikarjuna (2009) advocated the superiority of Emamectin benzoate $5 \mathrm{SG}$ and
Indoxacarb 14.5 SC in field bean ecosystem against pod borers. No information is traceable on the efficacy of chlorantraniliprole 18.5 SC against $A$. atkinsoni in field bean ecosystem. But it can be compared to studies by Neharkar et al., (2017) who proved the superiority of flubendiamide 20 WDG, chlorantraniliprole $18.5 \mathrm{SC}$ followed by spinosad $45 \mathrm{SC}$, emamectin benzoate $5 \mathrm{SG}$ and Indoxacarb 14.5 SC in pigeon pea against H. armigera.

\section{Population of $M$. vitrata}

The non-significant difference among the various treatments were surfaced one day before application of insecticides which indicated practically the uniform distribution of the $M$. vitrata population in the experimental plots (Table 5). The larval population ranged from 1.08 to 1.83 larvae/ plant.

However, one day after treatments were imposed, the least larval number was registered in treatment chlorantraniliprole 18.5 SC (0.43 larvae/ plant) which was on par with emamectin benzoate $5 \mathrm{SG}$ (0.52 larvae/ plant) and spinosad 45 SC (0.56 larvae/ plant). Which were followed by indoxacarb 14.5 SC (0.85 larvae/ plant) and thiodicarb 75 WP (0.99 larvae/ plant). The highest larval population was noticed in biopower $50 \mathrm{WP}$ treatment (1.64 larvae/ plant). However, all the treatments were significantly superior over control.

After 5 days of first spray, spinosad 45 SC was found superior over other treatments which harboured lowest larval population of 0.50 larvae/ plant which stood on par with chlorantraniliprole $\quad 18.5$ SC (0.62 larvae/ plant) and emamectin benzoate 5 SG (0.70 larvae/ plant). Which were followed by indoxacarb 14.5 SC (1.05 larvae/ plant) and thiodicarb $75 \mathrm{WP}$ (1.10 larvae/ plant). The 
highest larval population was noticed in biopower 50 WP treatment (1.95 larvae/ plant) which was on par with untreated control which recorded 2.25 larvae/ plant.

At 10 and 15 days after spraying also, a similar trend on the efficacy of insecticides was recorded. The larval population ranged from 1.54 to 2.93 larvae/ plant and 1.61 to 3.08 larvae/ plant at 10 days and 15 days after first spray, respectively. chlorantraniliprole 18.5 SC was found superior over rest of the insecticides which recorded lowest larval population of 1.54 larvae/ plant and 1.61 larvae/ plant at 10 and 15 days after spray, which was on par with spinosad 45 SC (1.69 and 1.91 larvae/ plant at 10 and 15 days after spray, respectively) and emamectin benzoate 5 SG (1.75 and 1.96 larvae/ plant at 10 and 15 days after spray, respectively). Which were followed by indoxacarb 14.5 SC (1.86 and 1.99 larvae/ plant at 10 and 15 days after spray, respectively) and thiodicarb $75 \mathrm{WP}$ (1.92 and 2.11 larvae/ plant at 10 and 15 days after spray, respectively). The highest larval population was noticed in biopower $50 \mathrm{WP}$ treatment (2.45 and 2.91 larvae/ plant at 10 and 15 days after spray, respectively). However, all the treatments were superior over control in efficacy.

\section{Second spray}

One day before treatment the larval population ranged from 1.61 to 3.08 larvae/ plant and there was significant difference in the larval population among the treatments (Table 5).

One day after treatments were imposed, among the selected insecticides, the lowest larval population was noticed in chlorantraniliprole $18.5 \mathrm{SC}$ treatment $(0.60$ larvae/ plant) which stood on par with spinosad 45 SC (0.65 larvae/ plant) and emamectin benzoate 5 SG (0.84 larvae/ plant). Which were followed by indoxacarb 14.5 SC (1.13 larvae/ plant) and thiodicarb 75 WP (1.15 larvae/ plant). The highest larval population was noticed in biopower $50 \mathrm{WP}$ treatment (2.09 larvae/ plant). However, all the treatments were significantly superior over control.

Five days after spray, the lowest larval population was noticed in chlorantraniliprole 18.5 SC treatment (1.05 larvae/ plant) which was on par with emamectin benzoate 5 SG (1.15 larvae/ plant), spinosad 45 SC (1.25 larvae/ plant) and thiodicarb $75 \mathrm{WP}$ (1.45 larvae/ plant). Which were followed by indoxacarb 14.5 SC (1.98 larvae/ plant). Whereas, the highest larval population was noticed in biopower 50 WP treatment (3.02 larvae/ plant). However, all the treatments were significantly superior over control.

Ten days after treatments were imposed, all the treatments were significantly superior over control. The larval population ranged from 1.76 to 4.00 larvae/ plant. The lowest larval population was recorded in chlorantraniliprole 18.5 SC with 1.76 larvae/ plant and was on par with the treatments viz., spinosad 45 SC (1.82 larvae/ plant), emamectin benzoate $5 \mathrm{SG}(1.90$ larvae/ plant), indoxacarb 14.5 SC (2.22 larvae/ plant) and thiodicarb 75 WP (2.34 larvae/ plant). The highest larval population was noticed in biopower 50 WP treatment (3.15 larvae/ plant). Fifteen days after spray, all the treatments were significantly superior over control. However, the lowest larval population was noticed in chlorantraniliprole 18.5 SC treatment (1.87 larvae/ plant) which was on par with the treatments emamectin benzoate 5 SG (2.06 larvae/ plant), spinosad 45 SC (2.26 larvae/ plant), indoxacarb 14.5 SC (2.39 larvae/ plant) and thiodicarb 75 WP (2.73 larvae/ plant).The highest larval population was noticed in Biopower $50 \mathrm{WP}$ treatment (3.76 larvae/ plant). 
After imposition of first and second spray the mean percent reduction of $M$. vitrata population was higher in chlorantraniliprole 18.5 SC treatment $(57.70 \%)$ followed by spinosad 45 SC (53.40\%) and emamectin benzoate $5 \mathrm{SG}(48.87 \%)$. However, the lowest per cent reduction over control was observed in biopower $50 \mathrm{WP}$ treatment (14.93\%).

After second spray, the treatments which harboured less larval population in the increasing order were chlorantraniliprole 18.5 SC < emamectin benzoate $5 \mathrm{SG}<$ spinosad 45 $\mathrm{SC}<$ indoxacarb 14.5 SC < thiodicarb $75 \mathrm{WP}$ $<$ azadirachtin $10000 \mathrm{ppm}<$ fenvelerate $0.4 \%$ $\mathrm{D}<$ lambda cyhalothrin $5 \mathrm{EC}<$ biopower 50 WP.

The present findings are in conformity with Kumar et al., (2015) who exhibited that, among newer insecticides, significantly least incidence of Maruca vitrata was recorded in indoxacarb 15.8 EC and chlorantraniliprole 18.5 in pigeon pea. Sreekanth et al., (2015) also manifested superiority of chlorantraniliprole $\quad 18.5 \quad \mathrm{SC}$ and flubendiamide $39.35 \mathrm{SC}$, followed by spinosad 45 SC $(6.21 \%)$ over other treatments. Reka and Mallapur (2007b) advocated the higher efficacy of emamectin benzoate, spinosad, indoxacarb and fenvalerate in field bean ecosystem against pod borers.

\section{Pod damage}

The percent pod damage incurred by pod borers registered at the time of harvest in different treatments is represented in Table 6. There was significant difference in pod damage among various treatments.

Among the selected insecticides, the least percent pod damage was noticed in chlorantraniliprole 18.5 SC treatment (12.57 $\%$ ) followed by emamectin benzoate $5 \mathrm{SG}$ $(15.83 \%)$ and spinosad 45 SC (17.60\%) which were statistically at par with each other. Which were followed by indoxacarb 14.5 SC (21.82\%) and thiodicarb $75 \mathrm{WP}$ (23.24\%). The highest pod damage was noticed in biopower 50 WP treatment (49.12 $\%)$ which was on par with untreated control $(52.99 \%)$. However, all the other treatments except biopower 50 WP treatment were significantly superior over control in terms of per cent pod damage.

The present findings are in practically agreement with Sreekanth et al., (2015) who advocated that pod damage due to legume pod borer was lowest in plots treated with chlorantraniliprole 18.5 SC, flubendiamide 39.35 SC and spinosad 45 SC as against control Patange and Chiranjeevi (2017) manifested that among various insecticides under study, the treatment application of Chlorantraniliprole $18.5 \mathrm{SC}$ showed the lowest pod damage due to pigeon pea pod borers.

\section{Yield and per cent yield increase over control}

The yield obtained in different treatments and per cent increase in yield over control was registered and analysed. The results showed significant difference in the yield in different treatments as indicated in Table 6.

Among the insecticidal molecules tested, the pod yield was maximum $(27.45 \mathrm{q} / \mathrm{ha})$ in chlorantraniliprole 18.5 SC followed by spinosad $45 \mathrm{SC}(25.48 \mathrm{q} / \mathrm{ha})$ and emamectin benzoate $5 \mathrm{SG}(24.80 \mathrm{q} / \mathrm{ha})$ which were statistically at par with each other. Which were followed by indoxacarb 14.5 SC (23.69 q/ha) and thiodicarb $75 \mathrm{WP}$ (22.95 q/ha). The lowest yield was noticed in biopower $50 \mathrm{WP}$ treatment (17.70 q/ha) which was on par with untreated control (16.71 q/ha). However, all the other treatments except biopower $50 \mathrm{WP}$ treatment were significantly superior over control in terms of yield. 
The per cent yield increase over control was also maximum (64.27 \%) in chlorantraniliprole 18.5 SC followed by spinosad 45 SC $(52.46 \%)$, emamectin benzoate $5 \mathrm{SG}(48.38 \%)$, indoxacarb 14.5 SC (41.74\%) and thiodicarb 75 WP (37.32\%), , lambda cyhalothrin 5 EC $(30.70 \%)$, azadirachtin 10000 ppm (23.89 \%), fenvelerate $0.4 \% \mathrm{D}(15.97 \%)$ and biopower $50 \mathrm{WP}(5.89 \%)$.

The results on yield in different plots of insecticidal treatments are practically in accordance with Rekha and Mallapur (2007b) who recorded highest yield of field bean in emamectin benzoate $5 \mathrm{SG}$ treated plots, followed by spinosad and indoxacarb which were on par with each other. Thejaswi et al., (2009) reported the superiority of thiodicarb 75 WP and spinosad 45 SC in obtaining maximum yield. Sreekanth et al., (2013) recorded highest yield in chlorantraniliprole treated plots followed by flubendiamide in pigeon pea.

\section{Cost economics}

Among the treatments, the highest net profit (Rs.63969 /ha) was registered in chlorantraniliprole 18.5 SC @ $0.15 \mathrm{ml} / \mathrm{l}$. This was followed by spinosad 45 SC @ $0.15 \mathrm{ml} / 1$ (Rs.58019/ha), emamectin benzoate 5 SG @ 0.2 g/l (Rs.56807/ha), indoxacarb 14.5 SC @ $0.30 \mathrm{ml} / \mathrm{l}$ (Rs.53486/ha) and thiodicarb 75 WP @ 0.60 g/l (Rs.51032 /ha). Likewise, the treatments viz., lambda cyhalothrin 5 EC @ $1 \mathrm{ml} / \mathrm{l}$, azadirachtin 10000 ppm @ $2 \mathrm{ml} / \mathrm{l}$, fenvelerate $0.4 \% \quad \mathrm{D} \quad @ \quad 25 \mathrm{~kg} / \mathrm{ha}$, and biopower 50WP @ $2 \mathrm{~g} / \mathrm{l}$ recorded a net profit of Rs. 485523, 45068, 41281 and 36098, per hectare respectively. However the lowest net profit (Rs. $34275.38 / \mathrm{ha}$ ) was recorded in untreated control (Table 7).

Table.1 Treatments details for the management of pod borer complex on field bean

\begin{tabular}{|r|l|c|c|c|}
\hline Sl. No. & \multicolumn{1}{|c|}{ Treatments } & Trade name & Dose (a.i. ha') & Dose (ml or g/l ) \\
\hline $\mathbf{1}$ & Indoxacarb 14.5 SC & Avaunt & 39.15 & 0.3 \\
\hline $\mathbf{2}$ & Biopower 50 WP & Biopower & 900 & 2 \\
\hline $\mathbf{3}$ & Thiodicarb75 WP & Larvin & 405 & 0.6 \\
\hline $\mathbf{4}$ & Chlorantraniliprole 18.5 SC & Corragen & 25 & 0.15 \\
\hline $\mathbf{5}$ & Emamectin benzoate 5 SG & Proclaim & 9 & 0.2 \\
\hline $\mathbf{6}$ & Spinosad 45 SC & Tracer & 60.75 & 0.15 \\
\hline $\mathbf{7}$ & Lambda cyhalothrin 5 EC & Karate & 45 & 1 \\
\hline $\mathbf{8}$ & Azadirachtin 10000 ppm & Neem baan & $2 \mathrm{ml} / 1$ & 2 \\
\hline $\mathbf{9}$ & Fenvelarate 0.4\% D & Fen dust & $0.2 \mathrm{~kg}^{-1}$ & $25 \mathrm{~kg} \mathrm{ha}^{-1}$ \\
\hline $\mathbf{1 0}$ & Untreated control & - & - & - \\
\hline
\end{tabular}


Table.2 Bio-efficacy of selected insecticides against E. atomosa in field bean, Kharif 2017

\begin{tabular}{|c|c|c|c|c|c|c|c|c|c|c|c|c|}
\hline \multirow{3}{*}{$\begin{array}{l}\text { Sl. } \\
\text { No. }\end{array}$} & \multirow[t]{3}{*}{ Treatments } & \multicolumn{10}{|c|}{ No. of larvae/ plant } & \multirow{3}{*}{$\begin{array}{l}\text { R O } \\
\text { C } \\
(\%)\end{array}$} \\
\hline & & \multicolumn{5}{|c|}{ I Spray } & \multicolumn{5}{|c|}{ II Spray } & \\
\hline & & DBS & 1 DAS & 5 DAS & 10 DAS & 15 DAS & DBS & 1 DAS & 5 DAS & 10 DAS & 15 DAS & \\
\hline 1 & $\begin{array}{l}\text { Indoxacarb } \\
14.5 \mathrm{SC}\end{array}$ & $\begin{array}{c}2.16 \\
(1.63)\end{array}$ & $\begin{array}{l}1.08^{\text {cd }} \\
(1.26)\end{array}$ & $\begin{array}{l}1.39^{\text {bcd }} \\
(1.37)\end{array}$ & $\begin{array}{l}2.44^{\text {cd }} \\
(1.71)\end{array}$ & $\begin{array}{c}3.61^{\mathrm{abcd}} \\
(2.03)\end{array}$ & $\begin{array}{c}3.61^{\mathrm{abcd}} \\
(2.03)\end{array}$ & $\begin{array}{l}1.22^{\text {bcde }} \\
(2.31)\end{array}$ & $\begin{array}{l}1.36^{\mathrm{bcd}} \\
(1.36)\end{array}$ & $\begin{array}{l}1.43^{\mathrm{abcd}} \\
(1.39)\end{array}$ & $\begin{array}{l}2.07^{\mathrm{abcd}} \\
(1.60)\end{array}$ & 74.41 \\
\hline 2 & Biopower $50 \mathrm{WP}$ & $\begin{array}{c}2.31 \\
(1.68)\end{array}$ & $\begin{array}{c}1.93^{\mathrm{i}} \\
(1.56)\end{array}$ & $\begin{array}{l}1.86^{\text {ghi }} \\
(1.48)\end{array}$ & $\begin{array}{l}3.34^{\text {ghi }} \\
(1.96)\end{array}$ & $\begin{array}{l}6.08^{\mathrm{i}} \\
(2.57)\end{array}$ & $\begin{array}{l}6.08^{\mathrm{i}} \\
(2.57)\end{array}$ & $\begin{array}{l}5.79^{\mathrm{i}} \\
(2.51)\end{array}$ & $\begin{array}{l}4.68^{\mathrm{h}} \\
(2.28)\end{array}$ & $\begin{array}{l}4.93^{\text {gh }} \\
(2.23)\end{array}$ & $\begin{array}{l}5.32^{\mathrm{i}} \\
(2.41)\end{array}$ & 34.24 \\
\hline 3 & Thiodicarb 75 WP & $\begin{array}{c}2.23 \\
(1.65)\end{array}$ & $\begin{array}{l}1.20^{\mathrm{de}} \\
(1.30)\end{array}$ & $\begin{array}{l}1.48^{\text {cde }} \\
(1.41)\end{array}$ & $\begin{array}{l}2.64^{\text {de }} \\
(1.77)\end{array}$ & $\begin{array}{l}4.14^{\mathrm{e}} \\
(2.15)\end{array}$ & $\begin{array}{l}4.14^{\mathrm{e}} \\
(2.15)\end{array}$ & $\begin{array}{l}1.18^{\text {bcd }} \\
(1.30)\end{array}$ & $\begin{array}{l}1.45^{\text {bcd }} \\
(1.40)\end{array}$ & $\begin{array}{l}1.58^{\mathrm{abcd}} \\
(1.44)\end{array}$ & $\begin{array}{l}2.21^{\text {bcde }} \\
(1.65)\end{array}$ & 72.68 \\
\hline 4 & $\begin{array}{l}\text { Chlorantraniliprole } \\
18.5 \mathrm{SC}\end{array}$ & $\begin{array}{c}2.54 \\
(1.74)\end{array}$ & $\begin{array}{l}0.47^{\mathrm{a}} \\
(0.98)\end{array}$ & $\begin{array}{l}1.04^{\mathrm{a}} \\
(1.24)\end{array}$ & $\begin{array}{l}1.27^{\mathrm{a}} \\
(1.33)\end{array}$ & $\begin{array}{l}3.30^{\mathrm{a}} \\
(1.95)\end{array}$ & $\begin{array}{l}3.30^{\mathrm{a}} \\
(1.95)\end{array}$ & $\begin{array}{l}0.78^{\mathrm{a}} \\
(1.13)\end{array}$ & $\begin{array}{r}0.88^{\mathrm{a}} \\
(1.17)\end{array}$ & $\begin{array}{l}1.12^{\mathrm{a}} \\
(1.27)\end{array}$ & $\begin{array}{r}1.67^{\mathrm{a}} \\
(1.47)\end{array}$ & 79.36 \\
\hline 5 & $\begin{array}{l}\text { Emamectin } \\
\text { benzoate } 5 \mathrm{SG}\end{array}$ & $\begin{array}{c}3.03 \\
(1.88)\end{array}$ & $\begin{array}{l}0.71^{\mathrm{abc}} \\
(1.10)\end{array}$ & $\begin{array}{l}1.15^{\mathrm{ab}} \\
(1.28)\end{array}$ & $\begin{array}{l}1.98^{\mathrm{abc}} \\
(1.57)\end{array}$ & $\begin{array}{l}3.46^{\mathrm{abc}} \\
(1.99)\end{array}$ & $\begin{array}{l}3.46^{\mathrm{abc}} \\
(1.99)\end{array}$ & $\begin{array}{l}1.00^{\mathrm{abc}} \\
(1.22)\end{array}$ & $\begin{array}{l}1.10^{\mathrm{abc}} \\
(1.26)\end{array}$ & $\begin{array}{l}1.24^{\mathrm{abc}} \\
(1.32)\end{array}$ & $\begin{array}{l}1.88^{\mathrm{ab}} \\
(1.54)\end{array}$ & 76.76 \\
\hline 6 & Spinosad 45 SC & $\begin{array}{c}2.63 \\
(1.77)\end{array}$ & $\begin{array}{l}0.59^{\mathrm{ab}} \\
(1.04)\end{array}$ & $\begin{array}{l}1.18^{\mathrm{abc}} \\
(1.30)\end{array}$ & $\begin{array}{l}1.47^{\mathrm{ab}} \\
(1.40)\end{array}$ & $\begin{array}{l}3.38^{\mathrm{ab}} \\
(1.97)\end{array}$ & $\begin{array}{l}3.38^{\mathrm{ab}} \\
(1.97)\end{array}$ & $\begin{array}{l}0.89^{\mathrm{ab}} \\
(1.18)\end{array}$ & $\begin{array}{l}0.95^{\mathrm{ab}} \\
(1.20)\end{array}$ & $\begin{array}{l}1.14^{\mathrm{ab}} \\
(1.28)\end{array}$ & $\begin{array}{l}1.93^{\mathrm{abc}} \\
(1.56)\end{array}$ & 76.14 \\
\hline 7 & $\begin{array}{l}\text { Lambda cyhalothrin } \\
5 \text { EC }\end{array}$ & $\begin{array}{c}2.89 \\
(1.84)\end{array}$ & $\begin{array}{l}1.23^{\mathrm{def}} \\
(1.32)\end{array}$ & $\begin{array}{l}1.51^{\mathrm{def}} \\
(1.42)\end{array}$ & $\begin{array}{l}2.78^{\text {def }} \\
(1.81)\end{array}$ & $\begin{array}{l}4.29^{\mathrm{ef}} \\
(2.19)\end{array}$ & $\begin{array}{l}4.29^{\mathrm{ef}} \\
(2.19)\end{array}$ & $\begin{array}{l}1.60^{\mathrm{ef}} \\
(1.45)\end{array}$ & $\begin{array}{l}1.67^{\mathrm{def}} \\
(1.47)\end{array}$ & $\begin{array}{l}2.25^{\mathrm{e}} \\
(1.66)\end{array}$ & $\begin{array}{l}2.72^{\mathrm{ef}} \\
(1.79)\end{array}$ & 66.38 \\
\hline 8 & $\begin{array}{l}\text { Azadirachtin } 10000 \\
\text { ppm }\end{array}$ & $\begin{array}{c}2.76 \\
(1.81)\end{array}$ & $\begin{array}{r}1.49^{\text {efgh }} \\
(1.41)\end{array}$ & $\begin{array}{c}1.65^{\text {defg }} \\
(1.47)\end{array}$ & $\begin{array}{l}3.14^{\text {efgh }} \\
(1.91)\end{array}$ & $\begin{array}{l}4.73^{\mathrm{fg}} \\
(2.29)\end{array}$ & $\begin{array}{l}4.73^{\mathrm{fg}} \\
(2.29)\end{array}$ & $\begin{array}{l}2.25^{\text {gh }} \\
(1.66)\end{array}$ & $\begin{array}{l}2.46^{\mathrm{efg}} \\
(1.72)\end{array}$ & $\begin{array}{l}2.93^{\mathrm{f}} \\
(1.85)\end{array}$ & $\begin{array}{l}3.06^{\mathrm{fg}} \\
(1.89)\end{array}$ & 62.18 \\
\hline 9 & $\begin{array}{l}\text { Fenvelerate } 0.4 \% \\
\text { D }\end{array}$ & $\begin{array}{c}2.20 \\
(1.64)\end{array}$ & $\begin{array}{l}1.36^{\text {defg }} \\
(1.36)\end{array}$ & $\begin{array}{l}1.83^{\text {gh }} \\
(1.53)\end{array}$ & $\begin{array}{l}2.83^{\operatorname{defg}} \\
(1.82)\end{array}$ & $\begin{array}{l}4.81^{\mathrm{gh}} \\
(2.30)\end{array}$ & $\begin{array}{l}4.81^{\text {gh }} \\
(2.30)\end{array}$ & $\begin{array}{l}2.14^{\mathrm{g}} \\
(1.62)\end{array}$ & $\begin{array}{l}2.56^{\mathrm{efg}} \\
(1.75)\end{array}$ & $\begin{array}{l}3.12^{\mathrm{fg}} \\
(1.90)\end{array}$ & $\begin{array}{l}3.91^{\text {gh }} \\
(2.10)\end{array}$ & 51.67 \\
\hline \multirow[t]{3}{*}{10} & Untreated control & $\begin{array}{c}2.92 \\
(1.85)\end{array}$ & $\begin{array}{l}3.14^{\mathrm{j}} \\
(1.91)\end{array}$ & $\begin{array}{c}3.43^{\mathrm{j}} \\
(1.98)\end{array}$ & $\begin{array}{l}4.31^{\mathrm{j}} \\
(2.19)\end{array}$ & $\begin{array}{l}6.59^{\mathrm{j}} \\
(2.66)\end{array}$ & $\begin{array}{l}6.59^{\mathrm{j}} \\
(2.66)\end{array}$ & $\begin{array}{l}7.38^{\mathrm{j}} \\
(2.81)\end{array}$ & $\begin{array}{l}7.66^{\mathrm{i}} \\
(2.86)\end{array}$ & $\begin{array}{l}7.84^{\mathrm{i}} \\
(2.89)\end{array}$ & $\begin{array}{l}8.09^{\mathrm{j}} \\
(2.93)\end{array}$ & - \\
\hline & SE $\mathbf{m} \pm$ & \multirow[t]{2}{*}{ NS } & 0.13 & 0.10 & 0.18 & 0.17 & 0.17 & 0.13 & 0.12 & 0.16 & 0.15 & \\
\hline & CD@ $5 \%$ & & 0.38 & 0.31 & 0.52 & 0.50 & 0.50 & 0.40 & 0.36 & 0.49 & 0.46 & \\
\hline
\end{tabular}

DBS: Day before spraying; DAS: Day after spraying; NS: Non significant; ROC: Reduction over control at 15 days after second spray; Figures in the parenthesis indicate $\sqrt{ } x+0.5$ transformed values; The values followed by same alphabets did not differ significantly as per DMRT. 
Table.3 Bio-efficacy of selected insecticides against H. armigera in field bean, Kharif 2017

\begin{tabular}{|c|c|c|c|c|c|c|c|c|c|c|c|c|}
\hline \multirow{3}{*}{$\begin{array}{l}\text { Sl. } \\
\text { No. }\end{array}$} & \multirow[t]{3}{*}{ Treatments } & \multicolumn{10}{|c|}{ No. of larvae/ plant } & \multirow{3}{*}{$\begin{array}{l}\text { R O } \\
\text { C } \\
(\%)\end{array}$} \\
\hline & & \multicolumn{5}{|c|}{ I Spray } & \multicolumn{5}{|c|}{ II Spray } & \\
\hline & & DBS & 1 DAS & $\begin{array}{l}5 \\
\text { DAS }\end{array}$ & $\begin{array}{l}10 \\
\text { DAS }\end{array}$ & $\begin{array}{l}15 \\
\text { DAS }\end{array}$ & DBS & 1 DAS & 5 DAS & $\begin{array}{l}10 \\
\text { DAS }\end{array}$ & $\begin{array}{l}15 \\
\text { DAS }\end{array}$ & \\
\hline 1 & $\begin{array}{l}\text { Indoxacarb } 14.5 \\
\text { SC }\end{array}$ & $\begin{array}{l}2.17 \\
(1.63)\end{array}$ & $\begin{array}{l}1.28^{\mathrm{de}} \\
(1.33)\end{array}$ & $\begin{array}{l}1.41^{\text {cde }} \\
(1.38)\end{array}$ & $\begin{array}{l}2.31^{\mathrm{d}} \\
(1.68)\end{array}$ & $\begin{array}{l}2.55^{\text {bcd }} \\
(1.75)\end{array}$ & $\begin{array}{l}2.55^{\mathrm{bcd}} \\
(1.75)\end{array}$ & $\begin{array}{l}1.17^{\mathrm{de}} \\
(1.29)\end{array}$ & $\begin{array}{l}1.67^{\mathrm{d}} \\
(1.47)\end{array}$ & $\begin{array}{l}2.21^{\mathrm{d}} \\
(1.65)\end{array}$ & $\begin{array}{l}2.40^{\mathrm{de}} \\
(1.97)\end{array}$ & 60.26 \\
\hline 2 & Biopower $50 \mathrm{WP}$ & $\begin{array}{l}2.54 \\
(2.74)\end{array}$ & $\begin{array}{l}2.00^{\mathrm{h}} \\
(1.58)\end{array}$ & $\begin{array}{l}2.27^{\mathrm{fgh}} \\
(1.66)\end{array}$ & $\begin{array}{l}3.04^{\mathrm{fgh}} \\
(1.88)\end{array}$ & $\begin{array}{l}3.17^{\mathrm{hi}} \\
(1.92)\end{array}$ & $\begin{array}{l}3.17^{\mathrm{hi}} \\
(1.92)\end{array}$ & $\begin{array}{l}2.91^{\mathrm{i}} \\
(1.85)\end{array}$ & $\begin{array}{l}3.04^{\text {ghi }} \\
(1.88)\end{array}$ & $\begin{array}{l}3.59^{\mathrm{h}} \\
(2.02)\end{array}$ & $\begin{array}{l}4.21^{\mathrm{g}} \\
(2.17)\end{array}$ & 30.30 \\
\hline 3 & Thiodicarb 75 WP & $\begin{array}{l}2.23 \\
(1.65)\end{array}$ & $\begin{array}{l}1.14^{\mathrm{cd}} \\
(1.28)\end{array}$ & $\begin{array}{l}1.36^{\mathrm{bcd}} \\
(1.36)\end{array}$ & $\begin{array}{l}2.41^{\text {de }} \\
(1.71)\end{array}$ & $\begin{array}{l}2.39^{\text {bcd }} \\
(1.70)\end{array}$ & $\begin{array}{l}2.39^{\mathrm{bcd}} \\
(1.70)\end{array}$ & $\begin{array}{l}0.92^{\text {bcd }} \\
(1.19)\end{array}$ & $\begin{array}{l}1.81^{\mathrm{de}} \\
(1.52)\end{array}$ & $\begin{array}{l}2.40^{\mathrm{de}} \\
(1.70)\end{array}$ & $\begin{array}{l}2.58^{\mathrm{de}} \\
(2.02)\end{array}$ & 57.28 \\
\hline 4 & $\begin{array}{l}\text { Chlorantraniliprole } \\
\text { 18.5 SC }\end{array}$ & $\begin{array}{l}2.31 \\
(1.68)\end{array}$ & $\begin{array}{l}0.53^{\mathrm{a}} \\
(1.01)\end{array}$ & $\begin{array}{l}0.94^{\mathrm{a}} \\
(1.20)\end{array}$ & $\begin{array}{l}1.17^{\mathrm{a}} \\
(1.29)\end{array}$ & $\begin{array}{l}2.25^{\mathrm{a}} \\
(1.66)\end{array}$ & $\begin{array}{l}2.25^{\mathrm{a}} \\
(1.66)\end{array}$ & $\begin{array}{l}0.51^{\mathrm{a}} \\
(1.00)\end{array}$ & $\begin{array}{l}0.93^{\mathrm{ab}} \\
(1.20)\end{array}$ & $\begin{array}{l}1.42^{\mathrm{a}} \\
(1.71)\end{array}$ & $\begin{array}{l}1.72^{\mathrm{a}} \\
(1.49)\end{array}$ & 71.52 \\
\hline 5 & $\begin{array}{l}\text { Emamectin } \\
\text { benzoate } 5 \mathrm{SG}\end{array}$ & $\begin{array}{l}2.20 \\
(1.64)\end{array}$ & $\begin{array}{l}0.78^{\mathrm{abc}} \\
(1.13)\end{array}$ & $\begin{array}{l}1.12^{\mathrm{abc}} \\
(1.27)\end{array}$ & $\begin{array}{l}1.56^{\mathrm{abc}} \\
(1.44)\end{array}$ & $\begin{array}{l}2.37^{\mathrm{abc}} \\
(1.69)\end{array}$ & $\begin{array}{l}2.37^{\mathrm{abc}} \\
(1.69)\end{array}$ & $\begin{array}{l}0.79^{\mathrm{abc}} \\
(1.14)\end{array}$ & $\begin{array}{l}0.92^{\mathrm{a}} \\
(1.19)\end{array}$ & $\begin{array}{l}1.65^{\mathrm{ab}} \\
(1.77)\end{array}$ & $\begin{array}{l}1.83^{\mathrm{abc}} \\
(1.53)\end{array}$ & 69.70 \\
\hline 6 & Spinosad 45 SC & $\begin{array}{l}2.63 \\
(1.77)\end{array}$ & $\begin{array}{l}0.65^{\mathrm{ab}} \\
(1.07)\end{array}$ & $\begin{array}{l}1.07^{\mathrm{ab}} \\
(1.25)\end{array}$ & $\begin{array}{l}1.34^{\mathrm{ab}} \\
(1.36)\end{array}$ & $\begin{array}{l}2.31^{\mathrm{ab}} \\
(1.68)\end{array}$ & $\begin{array}{l}2.31^{\mathrm{ab}} \\
(1.68)\end{array}$ & $\begin{array}{l}0.74^{\mathrm{ab}} \\
(1.11)\end{array}$ & $\begin{array}{l}1.09^{\mathrm{abc}} \\
(1.26)\end{array}$ & $\begin{array}{l}1.76^{\mathrm{abc}} \\
(1.81)\end{array}$ & $\begin{array}{l}1.73^{\mathrm{ab}} \\
(1.49)\end{array}$ & 71.35 \\
\hline 7 & $\begin{array}{l}\text { Lambda } \\
\text { cyhalothrin } 5 \mathrm{EC}\end{array}$ & $\begin{array}{l}2.89 \\
(1.84)\end{array}$ & $\begin{array}{l}1.30^{\text {def }} \\
(1.34)\end{array}$ & $\begin{array}{l}2.19^{\mathrm{fg}} \\
(1.64)\end{array}$ & $\begin{array}{l}2.68^{\text {defg }} \\
(1.78)\end{array}$ & $\begin{array}{l}2.74^{\mathrm{efg}} \\
(1.80)\end{array}$ & $\begin{array}{l}2.74^{\text {efg }} \\
(1.80)\end{array}$ & $\begin{array}{l}1.37^{\mathrm{ef}} \\
(1.37)\end{array}$ & $\begin{array}{l}2.83^{\mathrm{g}} \\
(1.82)\end{array}$ & $\begin{array}{l}2.86^{\text {def }} \\
(2.09)\end{array}$ & $\begin{array}{l}2.98^{\text {def }} \\
(2.07)\end{array}$ & 50.66 \\
\hline 8 & $\begin{array}{l}\text { Azadirachtin } \\
10000 \mathrm{ppm}\end{array}$ & $\begin{array}{l}2.77 \\
(1.81)\end{array}$ & $\begin{array}{l}1.42^{\operatorname{defg}} \\
(1.39)\end{array}$ & $\begin{array}{l}2.05^{\mathrm{f}} \\
(1.60)\end{array}$ & $\begin{array}{l}2.54^{\mathrm{def}} \\
(1.74)\end{array}$ & $\begin{array}{l}2.66^{\text {cdef }} \\
(1.78)\end{array}$ & $\begin{array}{l}2.66^{\text {cdef }} \\
(1.78)\end{array}$ & $\begin{array}{l}1.81^{\mathrm{gh}} \\
(1.52)\end{array}$ & $\begin{array}{l}1.91^{\mathrm{def}} \\
(1.55)\end{array}$ & $\begin{array}{l}2.81^{\mathrm{def}} \\
(1.82)\end{array}$ & $\begin{array}{l}2.99^{\mathrm{def}} \\
(1.87)\end{array}$ & 50.49 \\
\hline 9 & $\begin{array}{l}\text { Fenvelerate } 0.4 \% \\
\text { D }\end{array}$ & $\begin{array}{l}3.03 \\
(1.88)\end{array}$ & $\begin{array}{l}1.32^{\operatorname{defg}} \\
(1.35)\end{array}$ & $\begin{array}{l}2.39^{\text {gh }} \\
(1.70)\end{array}$ & $\begin{array}{l}2.73^{\operatorname{defg}} \\
(1.80)\end{array}$ & $\begin{array}{l}2.96^{\text {gh }} \\
(1.86)\end{array}$ & $\begin{array}{l}2.96^{\mathrm{gh}} \\
(1.86)\end{array}$ & $\begin{array}{l}1.74^{\mathrm{g}} \\
(1.50)\end{array}$ & $\begin{array}{l}2.85^{\text {gh }} \\
(1.83)\end{array}$ & $\begin{array}{l}2.84^{\text {def }} \\
(1.83)\end{array}$ & $\begin{array}{l}3.43^{\text {ef }} \\
(1.98)\end{array}$ & 43.21 \\
\hline \multirow[t]{3}{*}{10} & Untreated control & $\begin{array}{l}2.92 \\
(1.85)\end{array}$ & $\begin{array}{l}3.21^{\mathrm{i}} \\
(1.93)\end{array}$ & $\begin{array}{l}3.55^{\mathrm{h}} \\
(2.01)\end{array}$ & $\begin{array}{l}4.21^{\mathrm{i}} \\
(2.17)\end{array}$ & $\begin{array}{l}4.43^{\mathrm{i}} \\
(2.22)\end{array}$ & $\begin{array}{l}4.43^{\mathrm{i}} \\
(2.22)\end{array}$ & $\begin{array}{l}3.65^{\mathrm{j}} \\
(2.04)\end{array}$ & $\begin{array}{l}4.80^{\mathrm{j}} \\
(2.30)\end{array}$ & $\begin{array}{l}5.32^{\mathrm{i}} \\
(2.41)\end{array}$ & $\begin{array}{l}6.04^{\mathrm{h}} \\
(2.56)\end{array}$ & - \\
\hline & SE $\mathbf{m} \pm$ & \multirow[t]{2}{*}{ NS } & 0.12 & 0.10 & 0.25 & 0.10 & 0.10 & 0.12 & 0.20 & 0.13 & 0.19 & - \\
\hline & CD @ $5 \%$ & & 0.37 & 0.31 & 0.74 & 0.30 & 0.30 & 0.36 & 0.58 & 0.40 & 0.56 & - \\
\hline
\end{tabular}

DBS: Day before spraying; DAS: Day after spraying; NS: Non significant; ROC: Reduction over control at 15 days after second spray; Figures in the parenthesis indicate $\sqrt{ } \mathrm{x}+0.5$ transformed values; The values followed by same alphabet did not differ significantly as per DMRT. 
Table.4 Bio-efficacy of selected insecticides against A. atkinsoni in field bean, Kharif 2017

\begin{tabular}{|c|c|c|c|c|c|c|c|c|c|c|c|c|}
\hline \multirow{3}{*}{$\begin{array}{l}\text { Sl } \\
\text { No }\end{array}$} & \multirow[t]{3}{*}{ Treatments } & \multicolumn{10}{|c|}{ No. of larvae/ plant } & \multirow{3}{*}{$\begin{array}{l}\text { R O C } \\
(\%)\end{array}$} \\
\hline & & \multicolumn{5}{|c|}{ I Spray } & \multicolumn{5}{|c|}{ II Spray } & \\
\hline & & DBS & 1 DAS & 5 DAS & 10 DAS & 15 DAS & DBS & 1 DAS & 5 DAS & 10 DAS & 15 DAS & \\
\hline 1 & $\begin{array}{l}\text { Indoxacarb } 14.5 \\
\text { SC }\end{array}$ & $\begin{array}{l}2.32 \\
(1.68)\end{array}$ & $\begin{array}{l}1.24^{\mathrm{cd}} \\
(1.32)\end{array}$ & $\begin{array}{l}1.53^{\mathrm{bcd}} \\
(1.42)\end{array}$ & $\begin{array}{l}2.11^{\mathrm{bcd}} \\
(1.61)\end{array}$ & $\begin{array}{l}2.64^{\text {bcde }} \\
(1.77)\end{array}$ & $\begin{array}{l}2.64^{\text {bcde }} \\
(1.77)\end{array}$ & $\begin{array}{l}1.15^{\mathrm{bcd}} \\
(1.28)\end{array}$ & $\begin{array}{l}1.19^{\mathrm{abcd}} \\
(1.30)\end{array}$ & $\begin{array}{l}2.31^{\mathrm{de}} \\
(1.68)\end{array}$ & $\begin{array}{l}2.5^{\mathrm{bcd}} \\
(1.73)\end{array}$ & 48.35 \\
\hline 2 & Biopower $50 \mathrm{WP}$ & $\begin{array}{l}1.92 \\
(1.55)\end{array}$ & $\begin{array}{l}2.10^{\mathrm{efg}} \\
(1.61)\end{array}$ & $\begin{array}{l}2.26^{\mathrm{i}} \\
(1.66)\end{array}$ & $\begin{array}{l}2.68^{\text {cdef }} \\
(1.78)\end{array}$ & $\begin{array}{l}3.41^{\mathrm{ef}} \\
(1.98)\end{array}$ & $\begin{array}{l}3.41^{\mathrm{ef}} \\
(1.98)\end{array}$ & $\begin{array}{l}3.07^{\mathrm{i}} \\
(1.89)\end{array}$ & $\begin{array}{l}2.43^{\mathrm{hi}} \\
(1.71)\end{array}$ & $\begin{array}{l}2.66^{\text {ghi }} \\
(1.78)\end{array}$ & $\begin{array}{l}3.86^{\mathrm{fgh}} \\
(2.09)\end{array}$ & 20.58 \\
\hline 3 & Thiodicarb $75 \mathrm{WP}$ & $\begin{array}{l}1.96 \\
(1.57)\end{array}$ & $\begin{array}{l}1.38^{\mathrm{de}} \\
(1.37)\end{array}$ & $\begin{array}{l}1.41^{\mathrm{bcd}} \\
(1.38)\end{array}$ & $\begin{array}{l}2.12^{\mathrm{bcd}} \\
(1.62)\end{array}$ & $\begin{array}{l}2.31^{\mathrm{abcd}} \\
(1.68)\end{array}$ & $\begin{array}{l}2.31^{\mathrm{abcd}} \\
(1.68)\end{array}$ & $\begin{array}{l}1.24^{\text {bcde }} \\
(1.32)\end{array}$ & $\begin{array}{l}1.46^{\mathrm{de}} \\
(1.40)\end{array}$ & $\begin{array}{l}2.18^{\mathrm{d}} \\
(1.64)\end{array}$ & $\begin{array}{l}2.84^{\text {cde }} \\
(1.83)\end{array}$ & 41.56 \\
\hline 4 & $\begin{array}{l}\text { Chlorantraniliprole } \\
18.5 \mathrm{SC}\end{array}$ & $\begin{array}{l}2.28 \\
(1.67)\end{array}$ & $\begin{array}{l}0.63^{\mathrm{a}} \\
(1.06)\end{array}$ & $\begin{array}{l}0.88^{\mathrm{a}} \\
(1.17)\end{array}$ & $\begin{array}{l}1.95^{\mathrm{ab}} \\
(1.57)\end{array}$ & $\begin{array}{l}2.00^{\mathrm{a}} \\
(1.58)\end{array}$ & $\begin{array}{l}2.00^{\mathrm{a}} \\
(1.58)\end{array}$ & $\begin{array}{l}0.63^{\mathrm{a}} \\
(1.06)\end{array}$ & $\begin{array}{l}0.87^{\mathrm{a}} \\
(1.17)\end{array}$ & $\begin{array}{l}1.56^{\mathrm{a}} \\
(1.44)\end{array}$ & $\begin{array}{l}1.65^{\mathrm{a}} \\
(1.47)\end{array}$ & 66.05 \\
\hline 5 & $\begin{array}{l}\text { Emamectin } \\
\text { benzoate } 5 \mathrm{SG}\end{array}$ & $\begin{array}{l}2.43 \\
(1.71)\end{array}$ & $\begin{array}{l}0.84^{\mathrm{abc}} \\
(1.16)\end{array}$ & $\begin{array}{l}0.92^{\mathrm{ab}} \\
(1.19)\end{array}$ & $\begin{array}{l}1.76^{\mathrm{a}} \\
(1.50)\end{array}$ & $\begin{array}{l}2.08^{\mathrm{ab}} \\
(1.61)\end{array}$ & $\begin{array}{l}2.08^{\mathrm{ab}} \\
(1.61)\end{array}$ & $\begin{array}{l}0.88^{\mathrm{abc}} \\
(1.18)\end{array}$ & $\begin{array}{l}1.03^{\mathrm{abc}} \\
(1.24)\end{array}$ & $\begin{array}{l}1.70^{\mathrm{abc}} \\
(1.48)\end{array}$ & $\begin{array}{l}2.06^{\mathrm{abc}} \\
(1.60)\end{array}$ & 57.61 \\
\hline 6 & Spinosad 45 SC & $\begin{array}{l}2.00 \\
(1.58)\end{array}$ & $\begin{array}{l}0.75^{\mathrm{ab}} \\
(1.12)\end{array}$ & $\begin{array}{l}1.01^{\mathrm{abc}} \\
(1.23)\end{array}$ & $\begin{array}{l}2.06^{\mathrm{abc}} \\
(1.60)\end{array}$ & $\begin{array}{l}2.16^{\mathrm{abc}} \\
(1.63)\end{array}$ & $\begin{array}{l}2.16^{\mathrm{abc}} \\
(1.63)\end{array}$ & $\begin{array}{l}0.87^{\mathrm{ab}} \\
(1.17)\end{array}$ & $\begin{array}{l}0.92^{\mathrm{ab}} \\
(1.19)\end{array}$ & $\begin{array}{l}1.65^{\mathrm{ab}} \\
(1.47)\end{array}$ & $\begin{array}{l}1.90^{\mathrm{ab}} \\
(1.55)\end{array}$ & 60.91 \\
\hline 7 & $\begin{array}{l}\text { Lambda } \\
\text { cyhalothrin } 5 \text { EC }\end{array}$ & $\begin{array}{l}2.26 \\
(1.66)\end{array}$ & $\begin{array}{l}1.43^{\mathrm{def}} \\
(1.37)\end{array}$ & $\begin{array}{l}1.48^{\text {cde }} \\
(1.41)\end{array}$ & $\begin{array}{l}2.45^{\text {bcdef }} \\
(1.72)\end{array}$ & $\begin{array}{l}3.13^{\text {ef }} \\
(1.91)\end{array}$ & $\begin{array}{l}3.13^{\mathrm{ef}} \\
(1.91)\end{array}$ & $\begin{array}{l}1.27^{\text {cdef }} \\
(1.33)\end{array}$ & $\begin{array}{l}2.13^{\mathrm{h}} \\
(1.62)\end{array}$ & $\begin{array}{l}2.45^{\operatorname{defg}} \\
(1.72)\end{array}$ & $\begin{array}{l}3.33^{\mathrm{ef}} \\
(1.96)\end{array}$ & 31.48 \\
\hline 8 & $\begin{array}{l}\text { Azadirachtin } \\
10000 \mathrm{ppm}\end{array}$ & $\begin{array}{l}2.13 \\
(1.62)\end{array}$ & $\begin{array}{l}1.53^{\mathrm{def}} \\
(1.42)\end{array}$ & $\begin{array}{l}1.57^{\text {defg }} \\
(1.44)\end{array}$ & $\begin{array}{l}2.53^{\text {bcdef }} \\
(1.74)\end{array}$ & $\begin{array}{l}3.18^{\mathrm{ef}} \\
(1.92)\end{array}$ & $\begin{array}{l}3.18^{\mathrm{ef}} \\
(1.92)\end{array}$ & $\begin{array}{l}2.19^{\mathrm{h}} \\
(1.64)\end{array}$ & $\begin{array}{l}1.67^{\mathrm{ef}} \\
(1.47)\end{array}$ & $\begin{array}{l}2.35^{\text {def }} \\
(1.69)\end{array}$ & $\begin{array}{l}3.40^{\mathrm{efg}} \\
(1.97)\end{array}$ & 30.04 \\
\hline 9 & $\begin{array}{l}\text { Fenvelerate } 0.4 \% \\
\text { D }\end{array}$ & $\begin{array}{l}1.57 \\
(1.44)\end{array}$ & $\begin{array}{l}1.40^{\text {def }} \\
(1.38)\end{array}$ & $\begin{array}{l}1.69^{\text {defg }} \\
(1.48)\end{array}$ & $\begin{array}{l}2.48^{\text {bcdef }} \\
(1.73)\end{array}$ & $\begin{array}{l}3.36^{\mathrm{ef}} \\
(1.97)\end{array}$ & $\begin{array}{l}3.36^{\mathrm{ef}} \\
(1.97)\end{array}$ & $\begin{array}{l}1.62^{\mathrm{efg}} \\
(1.46)\end{array}$ & $\begin{array}{l}1.77^{\mathrm{efg}} \\
(1.51)\end{array}$ & $\begin{array}{l}2.64^{\text {efgh }} \\
(1.77)\end{array}$ & $\begin{array}{l}3.64^{\mathrm{efg}} \\
(2.03)\end{array}$ & 25.10 \\
\hline \multirow[t]{3}{*}{10} & Untreated control & $\begin{array}{l}1.68 \\
(1.48)\end{array}$ & $\begin{array}{l}2.64^{\mathrm{h}} \\
(1.77)\end{array}$ & $\begin{array}{l}2.80^{\mathrm{i}} \\
(1.82)\end{array}$ & $\begin{array}{l}3.08^{\mathrm{f}} \\
(1.89)\end{array}$ & $\begin{array}{l}3.66^{\mathrm{f}} \\
(2.04)\end{array}$ & $\begin{array}{l}3.66^{\mathrm{f}} \\
(2.04)\end{array}$ & $\begin{array}{l}3.85^{\mathrm{j}} \\
(2.09)\end{array}$ & $\begin{array}{l}3.92^{\mathrm{j}} \\
(2.10)\end{array}$ & $\begin{array}{l}4.24^{\mathrm{i}} \\
(2.18)\end{array}$ & $\begin{array}{l}4.86^{\mathrm{i}} \\
(2.31)\end{array}$ & - \\
\hline & \multirow{2}{*}{$\begin{array}{l}\text { SE m } \pm \text { CD @ } 5 \\
\%\end{array}$} & \multirow[t]{2}{*}{ NS } & 0.15 & 0.20 & 0.18 & 0.27 & 0.27 & 0.15 & 0.12 & 0.16 & 0.28 & - \\
\hline & & & 0.44 & 0.57 & 0.72 & 0.80 & 0.80 & 0.43 & 0.35 & 0.46 & 0.82 & - \\
\hline
\end{tabular}

DBS: Day before spraying; DAS: Day after spraying; NS: Non significant; ROC: Reduction over control at 15 days after second spray; Figures in the parenthesis indicate $\sqrt{x}+0.5$ transformed values; The values followed by same alphabets did not differ significantly as per DMRT 
Table.5 Bio-efficacy of selected insecticides against $M$. vitrata in field bean, Kharif 2017

\begin{tabular}{|c|c|c|c|c|c|c|c|c|c|c|c|c|}
\hline \multirow{3}{*}{$\begin{array}{l}\text { Sl. } \\
\text { No. }\end{array}$} & \multirow[t]{3}{*}{ Treatments } & \multicolumn{10}{|c|}{ No. of larvae/ plant } & \multirow{3}{*}{$\begin{array}{l}\text { RO } \\
\text { C } \\
(\%)\end{array}$} \\
\hline & & \multicolumn{5}{|c|}{ I Spray } & \multicolumn{5}{|c|}{ II Spray } & \\
\hline & & DBS & 1 DAS & 5 DAS & 10 DAS & 15 DAS & DBS & 1 DAS & 5 DAS & 10 DAS & $\begin{array}{l}15 \\
\text { DAS }\end{array}$ & \\
\hline 1 & $\begin{array}{l}\text { Indoxacarb } \\
14.5 \mathrm{SC}\end{array}$ & $\begin{array}{l}1.20 \\
(1.30)\end{array}$ & $\begin{array}{l}0.85^{\text {abcd }} \\
(1.16)\end{array}$ & $\begin{array}{l}1.04^{\text {cd }} \\
(1.24)\end{array}$ & $\begin{array}{l}1.86^{\mathrm{abcd}} \\
(1.50)\end{array}$ & $\begin{array}{l}1.99^{\mathrm{abcd}} \\
(1.58)\end{array}$ & $\begin{array}{l}1.99^{\mathrm{abcd}} \\
(1.58)\end{array}$ & $\begin{array}{l}1.13^{\mathrm{bcd}} \\
(1.28)\end{array}$ & $\begin{array}{l}1.98^{\mathrm{de}} \\
(1.57)\end{array}$ & $\begin{array}{l}2.22^{\mathrm{bcd}} \\
(1.65)\end{array}$ & $\begin{array}{l}2.39^{\text {abcd }} \\
(1.70)\end{array}$ & 45.93 \\
\hline 2 & $\begin{array}{l}\text { Biopower } \\
50 \text { WP }\end{array}$ & $\begin{array}{l}1.52 \\
(1.42)\end{array}$ & $\begin{array}{l}1.64^{\text {ghi }} \\
(1.46)\end{array}$ & $\begin{array}{l}1.95^{\mathrm{h}} \\
(1.57)\end{array}$ & $\begin{array}{l}2.45^{\text {gh }} \\
(1.72)\end{array}$ & $\begin{array}{l}2.91^{\mathrm{i}} \\
(1.85)\end{array}$ & $\begin{array}{l}2.91^{\mathrm{i}} \\
(1.85)\end{array}$ & $\begin{array}{l}2.09^{\mathrm{hi}} \\
(1.61)\end{array}$ & $\begin{array}{l}3.02^{\mathrm{i}} \\
(1.88)\end{array}$ & $\begin{array}{l}3.15^{\mathrm{fgh}} \\
(1.91)\end{array}$ & $\begin{array}{l}3.76^{\text {fghi }} \\
(2.06)\end{array}$ & 14.93 \\
\hline 3 & $\begin{array}{l}\text { Thiodicarb } \\
75 \text { WP }\end{array}$ & $\begin{array}{l}1.20 \\
(1.30)\end{array}$ & $\begin{array}{l}0.99^{\text {cde }} \\
(1.22)\end{array}$ & $\begin{array}{l}1.10^{\mathrm{de}} \\
(1.28)\end{array}$ & $\begin{array}{l}1.92^{\text {bcde }} \\
(1.56)\end{array}$ & $\begin{array}{l}2.11^{\text {bcde }} \\
(1.62)\end{array}$ & $\begin{array}{l}2.11^{\text {bcde }} \\
(1.62)\end{array}$ & $\begin{array}{l}1.15^{\text {bde }} \\
(1.28)\end{array}$ & $\begin{array}{l}1.45^{\text {abcd }} \\
(1.40)\end{array}$ & $\begin{array}{l}2.34^{\text {bcde }} \\
(1.69)\end{array}$ & $\begin{array}{l}2.73^{\text {bcde }} \\
(1.69)\end{array}$ & 38.24 \\
\hline 4 & $\begin{array}{l}\text { Chlorantrani } \\
\text { liprole } \\
18.5 \text { SC }\end{array}$ & $\begin{array}{l}1.83 \\
(1.53)\end{array}$ & $\begin{array}{l}0.43^{\mathrm{a}} \\
(0.96)\end{array}$ & $\begin{array}{l}0.62^{\mathrm{ab}} \\
(1.06)\end{array}$ & $\begin{array}{l}1.54^{\mathrm{a}} \\
(1.43)\end{array}$ & $\begin{array}{l}1.61^{\mathrm{a}} \\
(1.45)\end{array}$ & $\begin{array}{l}1.61^{\mathrm{a}} \\
(1.45)\end{array}$ & $\begin{array}{l}0.60^{\mathrm{a}} \\
(1.05)\end{array}$ & $\begin{array}{l}1.05^{\mathrm{a}} \\
(1.24)\end{array}$ & $\begin{array}{l}1.76^{\mathrm{a}} \\
(1.50)\end{array}$ & $\begin{array}{l}1.87^{\mathrm{a}} \\
(1.54)\end{array}$ & 57.70 \\
\hline 5 & $\begin{array}{l}\text { Emamectin } \\
\text { benzoate } 5 \\
\text { SG }\end{array}$ & $\begin{array}{l}1.11 \\
(1.27)\end{array}$ & $\begin{array}{l}0.52^{\mathrm{ab}} \\
(1.01)\end{array}$ & $\begin{array}{l}0.70^{\mathrm{abc}} \\
(1.10)\end{array}$ & $\begin{array}{l}1.75^{\mathrm{abc}} \\
(1.54)\end{array}$ & $\begin{array}{l}1.96^{\mathrm{abc}} \\
(1.57)\end{array}$ & $\begin{array}{l}1.96^{\mathrm{abc}} \\
(1.57)\end{array}$ & $\begin{array}{l}0.84^{\mathrm{abc}} \\
(1.16)\end{array}$ & $\begin{array}{l}1.15^{\mathrm{ab}} \\
(1.29)\end{array}$ & $\begin{array}{l}1.90^{\mathrm{abc}} \\
(1.55)\end{array}$ & $\begin{array}{l}2.06^{\mathrm{ab}} \\
(1.60)\end{array}$ & 53.40 \\
\hline 6 & $\begin{array}{l}\text { Spinosad } 45 \\
\text { SC }\end{array}$ & $\begin{array}{l}1.50 \\
(1.41)\end{array}$ & $\begin{array}{l}0.56^{\mathrm{abc}} \\
(1.03)\end{array}$ & $\begin{array}{l}0.50^{\mathrm{a}} \\
(1.00)\end{array}$ & $\begin{array}{l}1.69^{\mathrm{ab}} \\
(1.48)\end{array}$ & $\begin{array}{l}1.91^{\mathrm{ab}} \\
(1.55)\end{array}$ & $\begin{array}{l}1.91^{\mathrm{ab}} \\
(1.55)\end{array}$ & $\begin{array}{l}0.65^{\mathrm{ab}} \\
(1.07)\end{array}$ & $\begin{array}{l}1.25^{\mathrm{abc}} \\
(1.32)\end{array}$ & $\begin{array}{l}1.82^{\mathrm{ab}} \\
(1.69)\end{array}$ & $\begin{array}{l}2.26^{\mathrm{abc}} \\
(1.66)\end{array}$ & 48.87 \\
\hline 7 & $\begin{array}{l}\text { Lambda } \\
\text { cyhalothrin } \\
5 \mathrm{EC}\end{array}$ & $\begin{array}{l}1.54 \\
(1.43)\end{array}$ & $\begin{array}{l}1.25^{\mathrm{defg}} \\
(1.32)\end{array}$ & $\begin{array}{l}1.27^{\text {defg }} \\
(1.33)\end{array}$ & $\begin{array}{l}2.05^{\text {bcdef }} \\
(1.60)\end{array}$ & $\begin{array}{l}2.27^{\text {bcdef }} \\
(1.66)\end{array}$ & $\begin{array}{l}2.27^{\text {bcdef }} \\
(1.66)\end{array}$ & $\begin{array}{l}1.43^{\mathrm{defg}} \\
(1.39)\end{array}$ & $\begin{array}{l}2.05^{\text {defg }} \\
(1.60)\end{array}$ & $\begin{array}{l}2.56^{\text {bcdef }} \\
(1.75)\end{array}$ & $\begin{array}{l}3.46^{\text {efgh }} \\
(1.99)\end{array}$ & 21.72 \\
\hline 8 & $\begin{array}{l}\text { Azadirachti } \\
\text { n } 10000 \\
\text { ppm }\end{array}$ & $\begin{array}{l}1.65 \\
(1.47)\end{array}$ & $\begin{array}{l}1.60^{\mathrm{gh}} \\
(1.45)\end{array}$ & $\begin{array}{l}1.39^{\text {defg }} \\
(1.37)\end{array}$ & $\begin{array}{l}2.18^{\text {cdef }} \\
(1.64)\end{array}$ & $\begin{array}{l}2.40^{\text {cdef }} \\
(1.70)\end{array}$ & $\begin{array}{l}2.40^{\text {cdef }} \\
(1.70)\end{array}$ & $\begin{array}{l}1.39^{\mathrm{def}} \\
(1.37)\end{array}$ & $\begin{array}{l}2.14^{\text {defgh }} \\
(1.62)\end{array}$ & $\begin{array}{l}2.48^{\text {bcde }} \\
(1.73)\end{array}$ & $\begin{array}{l}2.99^{\text {cdef }} \\
(1.87)\end{array}$ & 32.35 \\
\hline 9 & $\begin{array}{l}\text { Fenvelerate } \\
0.4 \% \text { D }\end{array}$ & $\begin{array}{l}1.08 \\
(1.26)\end{array}$ & $\begin{array}{l}1.05^{\mathrm{def}} \\
(1.24)\end{array}$ & $\begin{array}{l}1.14^{\mathrm{def}} \\
(1.26)\end{array}$ & $\begin{array}{l}2.25^{\text {cdef }} \\
(1.66)\end{array}$ & $\begin{array}{l}2.35^{\text {cdef }} \\
(1.69)\end{array}$ & $\begin{array}{l}2.35^{\text {cdef }} \\
(1.69)\end{array}$ & $\begin{array}{l}1.56^{\mathrm{efgh}} \\
(1.44)\end{array}$ & $\begin{array}{l}2.02^{\text {def }} \\
(1.59)\end{array}$ & $\begin{array}{l}2.68^{\text {defg }} \\
(1.78)\end{array}$ & $\begin{array}{l}3.45^{\mathrm{efg}} \\
(1.99)\end{array}$ & 21.95 \\
\hline \multirow[t]{3}{*}{10} & $\begin{array}{l}\text { Untreated } \\
\text { control }\end{array}$ & $\begin{array}{l}1.39 \\
(1.37)\end{array}$ & $\begin{array}{l}2.19^{j} \\
(1.64)\end{array}$ & $\begin{array}{l}2.25^{\mathrm{i}} \\
(1.66)\end{array}$ & $\begin{array}{l}2.93^{\mathrm{gh}} \\
(1.85)\end{array}$ & $\begin{array}{l}3.08^{\mathrm{i}} \\
(1.89)\end{array}$ & $\begin{array}{l}3.08^{\mathrm{i}} \\
(1.89)\end{array}$ & $\begin{array}{l}3.04^{\mathrm{j}} \\
(1.88)\end{array}$ & $\begin{array}{l}3.59^{\mathrm{i}} \\
(2.02)\end{array}$ & $\begin{array}{l}4.00^{\mathrm{i}} \\
(2.12)\end{array}$ & $\begin{array}{l}4.42^{\mathrm{i}} \\
(2.22)\end{array}$ & - \\
\hline & SE $\mathbf{m} \pm$ & \multirow[t]{2}{*}{ NS } & 0.15 & 0.13 & 0.18 & 0.16 & 0.16 & 0.17 & 0.24 & 0.22 & 0.29 & - \\
\hline & CD@ $5 \%$ & & 0.44 & 0.38 & 0.54 & 0.49 & 0.49 & 0.52 & 0.71 & 0.64 & 0.87 & - \\
\hline
\end{tabular}


Table.6 The pod damage $(\%)$ and Yield $(\mathrm{q} / \mathrm{ha})$ in different treatments

\begin{tabular}{|c|c|c|c|c|}
\hline Sl. No. & Treatments & Pod damage (\%) & $\begin{array}{l}\text { Yield } \\
\text { (q/ha) }\end{array}$ & $\begin{array}{l}\% \text { Yield } \\
\text { increase over } \\
\text { control }\end{array}$ \\
\hline 1 & Indoxacarb $14.5 \mathrm{SC}$ & $21.82^{\mathrm{a}}(27.69)$ & $23.69^{\text {bcd }}$ & 41.74 \\
\hline 2 & Biopower 50 WP & $49.12^{\mathrm{i}}(44.48)$ & $17.70^{\mathrm{h}}$ & 5.89 \\
\hline 3 & Thiodicarb 75 WP & $23.24^{\text {cde }}(28.80)$ & $22.95^{\text {bcde }}$ & 37.32 \\
\hline 4 & Chlorantraniliprole $18.5 \mathrm{SC}$ & $12.57^{\mathrm{a}}(20.71)$ & $27.45^{\mathrm{a}}$ & 64.27 \\
\hline 5 & Emamectin benzoate $5 \mathrm{SG}$ & $15.83^{\mathrm{ab}}(23.28)$ & $24.80^{\mathrm{abc}}$ & 48.38 \\
\hline 6 & Spinosad 45 SC & $17.60^{\mathrm{abc}}(24.70)$ & $25.48^{\mathrm{ab}}$ & 52.46 \\
\hline 7 & Lambda cyhalothrin $5 \mathrm{EC}$ & $27.31^{\operatorname{def}}(31.45)$ & $21.84^{\text {cdef }}$ & 30.70 \\
\hline 8 & Azadirachtin 10000 ppm & $31.79^{\mathrm{fg}}(34.29)$ & $20.70^{\text {cdeg }}$ & 23.89 \\
\hline 9 & Fenvelerate $0.4 \%$ D & $42.80^{\mathrm{h}}(40.84)$ & $19.38^{\mathrm{degh}}$ & 15.97 \\
\hline 10 & Untreated control & $52.99^{i}(46.70)$ & $16.71^{\mathrm{gh}}$ & 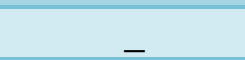 \\
\hline & \multirow{2}{*}{$\begin{array}{l}\text { SE m } \pm \\
\text { CD@ } 5 \%\end{array}$} & 2.06 & 1.40 & \multirow[t]{2}{*}{-} \\
\hline & & 6.12 & 4.17 & \\
\hline
\end{tabular}

Table.7 Cost economics of pod borer complex management in field bean, Kharif 2017

\begin{tabular}{|l|l|c|c|c|c|c|c|c|c|}
\hline $\begin{array}{l}\text { Sl. } \\
\text { No }\end{array}$ & Treatments & $\begin{array}{l}\text { Dose } \\
\text { (a.i./ } \\
\text { ha) }\end{array}$ & $\begin{array}{l}\text { Yield } \\
\text { (q/ha) }\end{array}$ & $\begin{array}{l}\text { Gross } \\
\text { return } \\
\text { (Rs.) }\end{array}$ & $\begin{array}{l}\text { Cost involved Rs /ha } \\
\text { Other } \\
\text { expenditure }\end{array}$ & $\begin{array}{c}\text { Total } \\
\text { insecticide }\end{array}$ & $\begin{array}{c}\text { Net } \\
\text { cost } \\
\text { (Rs.) }\end{array}$ & $\begin{array}{l}\text { C:B } \\
\text { profit } \\
\text { (Rs.) }\end{array}$ & \\
\hline $\mathbf{1}$ & ratio \\
\hline $\mathbf{2}$ & Indoxacarb 14.5 SC & 39.15 & 23.69 & 71058 & 16357 & 1215 & 17572 & 53486 & $1: 3.04$ \\
\hline $\mathbf{3}$ & Biopower 50 WP & 900 & 17.70 & 53085 & 16357 & 630 & 16987 & 36098 & $1: 2.13$ \\
\hline $\mathbf{4}$ & $\begin{array}{l}\text { Thiodicarb 75 WP } \\
\text { Chlorantraniliprole }\end{array}$ & 405 & 22.95 & 68840 & 16357 & 1451 & 17808 & 51032 & $1: 2.87$ \\
\hline & 18.5 SC & 27.45 & 82351 & 16357 & 2025 & 18382 & 63969 & $1: 3.48$ \\
\hline $\mathbf{5}$ & $\begin{array}{l}\text { Emamectin benzoate } \\
\text { 5 SG }\end{array}$ & 9 & 24.80 & 74388 & 16357 & 1224 & 17581 & 56807 & $1: 3.23$ \\
\hline $\mathbf{6}$ & Spinosad 45 SC & 60.75 & 25.48 & 76433 & 16357 & 2057 & 18414 & 58019 & $1: 3.15$ \\
\hline $\mathbf{7}$ & $\begin{array}{l}\text { Lambda cyhalothrin } \\
\text { 5 EC }\end{array}$ & 45 & 21.84 & 65522 & 16357 & 612 & 16969 & 48553 & $1: 2.86$ \\
\hline $\mathbf{8}$ & $\begin{array}{l}\text { Azadirachtin 10000 } \\
\text { ppm }\end{array}$ & $2 \mathrm{ml} / 1$ & 20.70 & 62111 & 16357 & 686 & 17043 & 45068 & $1: 2.64$ \\
\hline $\mathbf{9}$ & Fenvelerate 0.4 \% D & $0.2 \mathrm{~kg}$ & 19.38 & 58138 & 16357 & 500 & 16857 & 41281 & $1: 2.45$ \\
\hline $\mathbf{1 0}$ & Untreated control & 0 & 16.71 & 50132 & 15857 & - & 15857 & 34275 & $1: 2.16$ \\
\hline
\end{tabular}

*Average price of field bean: Rs.30000 per quintal

Figures in the parentheses indicate arc sine transformed values; The values followed by same alphabets did not differ significantly as per DMRT.

Among the treatments, the highest cost benefit ratio was obtained in chlorantraniliprole $18.5 \mathrm{SC}$ @ $0.15 \mathrm{ml} / \mathrm{l}(1$ :
3.48). This was followed by emamectin benzoate 5 SG @ 0.2 g/l (1: 3.23), spinosad 45 SC @ 0.15 ml/1 (1: 3.15), indoxacarb 14.5 
SC @ $0.30 \mathrm{ml} / 1$ (1: 3.04) and thiodicarb 75 WP @ 0.60 g/l (1: 2.87). Likewise, the treatments viz., lambda cyhalothrin 5 EC @ $1 \mathrm{ml} / 1$, azadirachtin 10000 ppm @ $2 \mathrm{ml} / 1$ and fenvelerate $0.4 \%$ D @ $25 \mathrm{~kg} / \mathrm{ha}$ recorded a cost benefit ratio of Rs. 1: 2.86, 1: 2.64 and 1: 2.45 respectively. However, the lowest costbenefit ratio biopower 50 WP @ 2 g/l (1: 2.13) and untreated control (1: 2.16) (Table 7).

The present findings are in accordance with Patange and chiranjeevi (2017) who documented highest cost benefit ratio in rynaxypyr (chlorantraniliprole) treated plots. Whereas, Wadaskar et al., (2013) recorded highest cost benefit ratio (C: B) in spinosad 45 SC. However, Sreekanth et al., (2015) reported that the cost effectiveness of chlorantraniliprole $\quad 18.5 \quad \mathrm{SC}$ and flubendiamide $39.35 \mathrm{SC}$ was high and very favourable with incremental cost-benefit ratios, followed by indoxacarb 14.5 SC, emamectin benzoate $5 \mathrm{SG}$ and spinosad 45 SC.

In the present investigations the chlorantraniliprole 18.5 SC @ $0.15 \mathrm{ml} / \mathrm{l}$, followed by emamectin benzoate 5 SG @ 0.2 $\mathrm{g} / 1$ and spinosad $45 \mathrm{SC} @ 0.15 \mathrm{ml} / 1$ showed high effectiveness against pest this may be due to their uniform spread, long lasting effect and novel mode of action.

\section{Acknowledgement}

Authors thankful to College of Agriculture, VC form, Mandya for providing field and lab facility. Also thank Dr. S. Ramesh, UAS, GKVK, Bangalore for providing seed material.

\section{References}

Chakravarthy, A. K., 1983. Relative abundance of field bean (Lablab niger
Medick) pod borers and distribution patterns of the borer, Adisura atkinsoni Moore. Insect Sci. Applic., 4(4): 401406.

Fleming, R. and Ratnakaran., 1985. Evaluating single treatment data using abbot's formula with modification. J. Econ. Entomol., 78: 1179.

Gomez, K. Q. and Gomez, A. A., 1984. Statistical procedures for agricultural research with emphasis on rice. International Rice Research Institute, Los Banos, Philippines, pp. 268.

Govindan, R., 1974. Insects of the field bean, Lablab niger var. lignosus Medikus with special reference to the biology and ecology of the pod borer, Adisura atkinsoni Moore (Lepidoptera: Noctuidae). M. Sc. (Agri.) Thesis, University of Agricultural Sciences, Bangalore, p.1-34.

Hosmand, R. A., 1988. Statistical Methods for Agricultural Sciences. Timber press, Portland, Oregon, USA, pp. 405.

Jat, G. C., Agrawal, V. K. and Deshwal, H. L., 2017. Bio-efficacy of newer molecules against pod borer complex of Indian bean, Lablab purpureus (L.) Sweet. Int. J. Agric. Sci., 13(2): 300-304.

Katagihallimath, S. S. and Siddappaji, C., 1962. Observations on the incidence of lepidopteran pod borers of Dolichos lablab and the results of preliminary insecticidal trails to control them. 2nd All India Congress of Zoology, pp. 59.

Kumar, G. S., Krishna, T. M., Prasanthi, L., Sudhakar, P. and Devaki, K., 2015. Morphological and biochemical traits associated with resistance to pod fly, Melanagromyza obtusa (malloch) in pigeonpea. Int. J. Appl. Biol, Pharm. Technol., 6(3): 134-141.

Mallikarjuna, J., 2009. Studies on pod borers of Dolichos bean, Lablab purpureas L. (sweet) and their management. M. Sc. (Agri) Thesis, University of Agricultural 
Sciences, Bangalore, India.

Mallikarjunappa, 1989. Field bean pod borer complex with reference to germplasm screening, life table, action threshold, crop loss and chemical control of Adisura atkinsoni. Ph. D. Thesis, University of Agricultural Sciences, Bangalore, p. 115.

Neharkar, P. S., Dhepe, V. R., Dhurve, N. G., Nandanwar, V. N., Gawande R. W., and Masal, R., 2017. Evaluation of some newer insecticides in comparison with botanicals against Heliothis armigera on Pigeonpea, Cajanus cajan. Int. J. Chem. Stud., 5(6): 248-252.

Patange, N.R. and Chiranjeevi, B., 2017. Bioefficacy of newer insecticides against pigeonpea (Cajanus cajan L. Millsp.) pod borers. J. Entomol. Zool. Stud., 5(3): 28-31.

Rekha, S. and Mallapur, C. P., 2007. Efficacy of indigenous materials and new molecules against pod borer complex of Dolichos bean. Karnataka J. Agric. Sci., 20(2): 414-416.

Singh, A. K. and Kumar, A., 2012. Evaluation of new molecules in IPM modules against Helicoverpa armigera (Hubner) in chickpea. Ann. Plant Protec. Sci., 20(1): 19-23.

Sreekanth, M., Lakshmi, M. S. M. and Rao, Y. K., 2013. Bio-efficacy and economics of certain new insecticides against gram pod borer, Helicoverpa armigera (hubner) infesting pigeon pea (Cajanus cajan L.). Int. J. Plant Anim. Environ. Sci., 11(4): 11-15.

Sreekanth, M., Lakshmi, M. S. M. and Rao, Y. K., 2015. Efficacy and economics of certain new generation novel insecticides against legume pod borer, Maruca vitrata (Geyer) on pigeonpea (Cajanus cajan L.). J. Appl. Biol. Biotechnol., 3(3): 7-10. Thejaswi, L., Naik, M. I. and Manjunatha, M., 2009. Bio-efficacy of new insecticide molecules against pod borer complex of field bean, Lablab purpureus (L.). Karnataka J. Agric. Sci., 43(1): 73-79.

Wadaskar, R. M., Balkare, S. K. and Patil, A. N., 2013. Field efficacy of newer insecticides against pod borer complex of pigeon pea. J. Food Legumes, 26(1): 6266.

\section{How to cite this article:}

Rashmi, K.M., K.N. Muniswamy Gowda, B. Tambat, N. Umashankar Kumar and Vijayakumar, L. 2020. The Bioefficacy of Selected Insecticides against Field Bean (Lablab purpureus) Pod Borer Complex. Int.J.Curr.Microbiol.App.Sci. 9(06): 3906-3923. doi: https://doi.org/10.20546/ijcmas.2020.906.460 